\title{
Surface Ozone Concentration over Russian Territory in the First Half of 2020
}

\author{
V. V. Andreev ${ }^{a}$, M. Yu. Arshinov ${ }^{b}$, B. D. Belan ${ }^{b}$ * , D. K. Davydov ${ }^{b}$ N. F. Elansky ${ }^{c}$ G. S. Zhamsueva ${ }^{d}$, \\ A. S. Zayakhanov ${ }^{d}$, G. A. Ivlev ${ }^{b}$, A. V. Kozlov ${ }^{b}$, S. N. Kotel'nikov ${ }^{e}$, I. N. Kuznetsova ${ }^{f}$, V. A. Lapchenko ${ }^{g}$, \\ E. A. Lezina ${ }^{h}$, O. V. Postylyakov ${ }^{c}$, D. E. Savkin ${ }^{b}$, I. A. Senik ${ }^{c}$, E. V. Stepanov ${ }^{e}$, G. N. Tolmachev ${ }^{b}$, \\ A. V. Fofonov ${ }^{b}$, I. V. Chelibanov $i$, V. P. Chelibanov ${ }^{i}$, and V. V. Shirotov ${ }^{j}$ \\ a Peoples' Friendship University of Russia, Moscow, 117198 Russia \\ ${ }^{b}$ V.E. Zuev Institute of Atmospheric Optics, Siberian Branch, Russian Academy of Sciences, Tomsk, 634055 Russia \\ ${ }^{c}$ Obukhov Institute of Atmospheric Physics, Russian Academy of Sciences, Moscow, 119017 Russia \\ ${ }^{d}$ Institute of Physical Materials Science, Siberian Branch, Russian Academy of Sciences, Ulan-Ude, 670047 Russia \\ ${ }^{e}$ Prokhorov General Physics Institute, Russian Academy of Sciences, Moscow, 119333 Russia \\ ${ }^{f}$ Hydrometeorological Centre of Russia, Moscow, 123242 Russia \\ ${ }^{g}$ Vyazemsky Karadag Scientific Station-Nature Reserve of the Russian Academy of Sciences, Branch of Kovalevsky Institute \\ of Biology of the Southern Seas, Russian Academy of Sciences, Kurortnoe settlement, Feodosia, 298188 Russia \\ ${ }^{h}$ Mosecomonitoring, Moscow, 119019 Russia \\ ${ }^{i}$ Instrument-Making Company OPTEK, St. Petersburg, 199178 Russia \\ ${ }^{j}$ RPO Tayfun, Obninsk, Kaluzhskaya oblast, 249038 Russia \\ *e-mail: bbd@iao.ru
}

Received August 10, 2020; revised August 10, 2020; accepted August 17, 2020

\begin{abstract}
Information on the ozone concentration in the surface air and troposphere in the first half of 2020 is presented. The data were acquired at 13 stations in different Russian regions; vertical distributions were obtained with the use of an aircraft laboratory. The excess over the Russian Federation hygienic standards is assessed; the daily average ozone concentration is found to be regularly higher the maximum permissible concentrations at most stations. At some stations, there are features the seasonal variations in the ozone concentration in the period under study different from previous years.
\end{abstract}

Keywords: atmosphere, vertical profile, air, concentration, ozone, maximum permissible concentration, surface layer, boundary layer

DOI: $10.1134 / \mathrm{S} 1024856020060184$

\section{INTRODUCTION}

Ozone is a first hazard class substance according to hygienic standards. In the surface air layer, it interacts with biological and human-made objects and shows its toxic properties. Ozone in high concentrations strongly inhibits the vital activity of plants and negatively affects human beings. As shown by biological and medical studies [1-3], ozone in the troposphere is a potent poison and has such properties as mutagenicity, carcinogenicity, and a radiomimetic effect (the effect on blood similar to that of ionizing radiation), in addition to general toxicity, in terms of which ozone is superior to hydrocyanic acid. Ozone is also a powerful oxidizer which destroys rubber and gum, oxidizes many metals, even of the platinum group [4]. Having a long lifetime in the atmosphere (from several days to several months) and strong radiation absorption lines, tropospheric ozone can play a significant role in the greenhouse effect. According to estimates [5], its contribution to the total air heating due to the solar radiation absorption by greenhouse gases exceeds $8 \%$.

An extremely dangerous consequence of high ozone concentrations is smog events in cities. The first smog event was recorded in Los Angeles [6]. A more detailed analysis carried out later [7] showed that the main source of ozone-forming substances were emissions from vehicles. Since then, photochemical smog has become common in industrialized cities in the world. To get rid of air pollution due to all kinds of emissions in the megalopolis of Mexico City, the household sector and transport were modified to run on gas. That measure decreased the concentration of suspended particles (one of the components of urban pollution), but caused dangerously high concentrations of tropospheric ozone [8]. According to [9], Russia can repeat the sad experience of Mexico City. 
Table 1. Russian stations where surface ozone concentration is measured

\begin{tabular}{|c|c|c|c|c|c|}
\hline Station & Region & Type & Latitude & Longitude & $\begin{array}{c}\text { Altitude } \\
\text { above sea level, m }\end{array}$ \\
\hline OPTEC-PR & Leningrad region & Background & $60^{\circ} 42^{\prime} 59^{\prime \prime}$ & $30^{\circ} 03^{\prime} 24^{\prime \prime}$ & 40 \\
\hline OPTEC-P & St. Petersburg & Urban & $59^{\circ} 56^{\prime} 27^{\prime \prime}$ & $30^{\circ} 15^{\prime} 14^{\prime \prime}$ & 8 \\
\hline OPTEC-N & St. Petersburg & Urban & $59^{\circ} 55^{\prime} 23^{\prime \prime}$ & $30^{\circ} 23^{\prime} 17^{\prime \prime}$ & 1 \\
\hline Karadag SBEM & Crimean Peninsula & Background & $44^{\circ} 55^{\prime}$ & $35^{\circ} 14^{\prime}$ & 180 \\
\hline Obninsk & Kaluga Region & Urban & $55^{\circ} 05^{\prime} 48^{\prime \prime}$ & $36^{\circ} 36^{\prime} 36^{\prime \prime}$ & 175 \\
\hline RUDN & Moscow & Urban & $55^{\circ} 42^{\prime} 37^{\prime \prime}$ & $37^{\circ} 36^{\prime} 78^{\prime \prime}$ & 149 \\
\hline ACAP "Maryino" & Moscow & Urban & $55^{\circ} 39^{\prime} 14^{\prime \prime}$ & $37^{\circ} 44^{\prime} 58^{\prime \prime}$ & 135 \\
\hline ACAP "Gagarin Square" & Moscow & Urban & $55^{\circ} 42^{\prime} 31^{\prime \prime}$ & $37^{\circ} 34^{\prime} 57^{\prime \prime}$ & 120 \\
\hline KHMSS & Northern Caucasus & High mountain & $44^{\circ} 41^{\prime} 31^{\prime \prime}$ & $43^{\circ} 39^{\prime} 40^{\prime \prime}$ & 2096 \\
\hline Vyatskie Polyany & Kirov Region & Background & $56^{\circ} 13^{\prime} 33^{\prime \prime}$ & $51^{\circ} 03^{\prime} 56^{\prime \prime}$ & 74 \\
\hline Fonovaya observatory & Tomsk Region & Background & $56^{\circ} 25^{\prime} 07^{\prime \prime}$ & $84^{\circ} 04^{\prime} 27^{\prime \prime}$ & 80 \\
\hline TOR & Tomsk Region & Suburban & $56^{\circ} 28^{\prime} 41^{\prime \prime}$ & $85^{\circ} 03^{\prime} 15^{\prime \prime}$ & 133 \\
\hline Ulan-Ude & Buryatia & Suburban & $51^{\circ} 86^{\prime} 79^{\prime \prime}$ & $107^{\circ} 86^{\prime} 71^{\prime \prime}$ & 523 \\
\hline
\end{tabular}

The world community estimated the scale of the problem of tropospheric ozone and the need to eliminate its high concentrations in the air long ago. Tropospheric ozone is considered the main air pollutant in the United States, Mexico, Canada, and Western Europe. Therefore, ozone is monitored there both in background and urban conditions. Ozone is studied by hundreds of teams from scientific institutions, environmental organizations, and universities. Ozone pollution is of a transboundary nature; therefore, there are international agreements for ozone monitoring, analysis of effects, and information about sources of emissions of tropospheric ozone precursors, e.g., within the Convention on Long-Range Transboundary Air Pollution. The Russian Federation (RF) is a party to this Convention, but has not yet ratified the Protocol to Combating Acidifying, Eutrophying, and Ground-level Ozone (1999 Goteborg Protocol; https://www.unece.org/fileadmin/AM/env/lrtap/full\% 20text/1999. Multi.R.Amended.2005.pdf). The population of many countries is informed about the current surface ozone concentrations and expected in the coming days (e.g., https://www.academia.edu/7747737/ Global_Ozone_Project_Curriculum_for_GO3_Project). State emergency authorities included ozone in the list of objects for rapid response. Therefore, any new information about ozone is relevant.

The problem of tropospheric ozone did not find a proper public and scientific response in Russia. Surface ozone is monitored by state organizations in a few large cities: Moscow, St. Petersburg, Kazan, Tomsk, Krasnoyarsk, Sochi, Apatity (Murmansk region), and Ulan-Ude (Table 1), as well as at initiatively organized stations (Obninsk and Vyatskiye Polyany), within international projects [10].

The purpose of a series of publications planned, including the present review, is to inform the scientific community about the surface ozone content, the reasons for its variability, and the conformity of the ozone concentrations recorded at different monitoring sites to the RF hygienic standards.

\section{STATIONS AND TOOLS USED}

There is no unified state system for ozone monitoring in the Russian Federation. The surface ozone concentrations were measured by groups of enthusiasts without centralized funding, but with funds from different sources, at almost half of sites given in Table 1. Hence, different instruments and approaches were used. In this section, we provide a detailed description of the Russian stations, where surface ozone concentration is measured, and of the tools used and calibration procedures.

The stations can be divided into three types by their location: urban, including traffic, suburban, and background. The station types and coordinates are given in Table 1 in descending (from west to east) longitude.

OPTEK-N station is located in St. Petersburg, near the Alexander Nevsky Lavra. The sampling probe of the station is fixed at an altitude of $2.5 \mathrm{~m}$ above the ground. OPTEK-P station is also located in St. Petersburg, on Vasilyevsky Island. Its sampling probe is fixed at an altitude of $16 \mathrm{~m}$ above the ground. OPTEK-PR station is in the Leningrad region, at Gromovo station, Priozersky district. The sampling is carried out at an altitude of $2.5 \mathrm{~m}$. Commercially produced $3.02 \mathrm{P}-\mathrm{A}$ chemiluminescent analyzers are used for measuring ozone at all these stations. The surface concentration of the metastable oxygen form ${ }^{1} \Delta_{\mathrm{g}}\left(\mathrm{O}_{2}\right)$ has also been measured at the OPTEK-PR station with an analyzer model 102 for several years. The surface concentrations of $\mathrm{NO}, \mathrm{NO}_{2}, \mathrm{SO}_{2}, \mathrm{CO}, \mathrm{PM} 10, \mathrm{PM} 2.5$ and PM1.0 
are also monitored at OPTEK-N and OPTEK-P stations. The atmospheric monitoring stations include AIIS-VP22 meteorological complexes (based on a Vantage Pro-2 weather station) for measuring meteorological parameters. All measuring tools at the stations are certified and annually verified. A typical OPTEK station is described in detail in [11].

The Karadag State Natural Reserve is located at the Karadag Mountains on the southeastern Crimean coast at a considerable distance from sources of industrial emissions. The Karadag scientific station of background environmental monitoring (SBEM) - a Natural Reserve of the Russian Academy of Sciences, a Branch of Kovalevsky Institute of Biology of the Southern Seas, Russian Academy of Sciences-is situated on the territory of the Reserve, on the northeastern slope of Svyataya Mount, in an oak-pistachio sparse forest with elements of herb-grass communities, including rare and endemic species. There are artificial plantings of Crimean pine and oak-hornbeam forest in the immediate vicinity of SBEM. The distance to the nearest settlement Koktebel is about $1.5 \mathrm{~km}$. The station is separated from the sea by the Kok-Kaya ridge (320 $\mathrm{m}$ above sea level).

An APOA-370 optical gas analyzer (HORIBA, Japan) is used to measure the surface ozone concentration at the Karadag SBEM (the principle of operation is based on absorption in the UV region). Sampling is carried out with the use of Teflon tubes at an altitude of $2 \mathrm{~m}$. The gas analyzer is calibrated monthly using an APMC-370 generator (HORIBA) and is calibrated annually at the Mendeleev All-Russian Research Institute of Metrology (VNIIM), St. Petersburg. The meteorological parameters are measured by TROPOSPHERE-N (Ukraine) and WS-600 (Germany) weather stations [12].

The Obninsk station is located within the boundaries of Obninsk-the first science city in the Russian Federation. Perhaps, it should be classified as a suburban station, because there are no large industrial enterprises, and the regional centers (Moscow and Kaluga) are located at a distance of $\sim 100 \mathrm{~km}$. Air sampling is organized at an altitude of $2.5 \mathrm{~m}$. An F-105 optical gas analyzer (OPTEK, St. Petersburg) is used for the analysis of surface ozone concentrations; it is calibrated in accordance with the schedule. The measurements are carried out in the continuous (aroundthe-clock) automatic long-term monitoring mode; one-time 20 -minute values are initial data. In addition to surface ozone concentrations, $\mathrm{NO}, \mathrm{NO}_{2}, \mathrm{CO}, \mathrm{CH}_{4}$, $\mathrm{SO}_{2}, \mathrm{H}_{2} \mathrm{~S}, \mathrm{NH}_{3}$, and hydrocarbons, the mass concentration of aerosol particles of different size, and main meteorological parameters are measured at the station.

The automatic station for monitoring surface ozone and its predictors and measuring main meteorological parameters was organized at the end of 2019 at the Peoples' Friendship University of Russia (RUDN) at the center of Moscow, within the Third Ring Road, with the participation of Prokhorov General Physics Institute, Russian Academy of Sciences. The station is surrounded by buildings, several squares, and boulevards; highways, which are the main sources of ozone precursors, are at a distance of no less than $\sim 1 \mathrm{~km}$ (the Garden Ring Road, Leninsky Prospect, Varshavskoye Shosse, and the Third Transport Ring); there are no industrial facilities within $1 \mathrm{~km}$.

In addition to surface ozone, $\mathrm{NO}, \mathrm{NO}_{2}, \mathrm{CO}, \mathrm{CH}_{4}$, and hydrocarbons are monitored; the mass concentration of aerosol particles of different size and main meteorological parameters are measured. A 3-02P chemiluminescent gas analyzer, developed and manufactured by OPTEK, is used for ozone measurements. Air sampling is carried out in the courtyard of the RUDN complex from an altitude of $\sim 5 \mathrm{~m}$ through standard Teflon samplers, which are part of analytical equipment. The measurements are carried out in the continuous monitoring mode. The current values of the parameters measured are recorded once a minute and stored in a database.

A regional environmental monitoring network of Mosecomonitoring, which is an authorized environmental monitoring organization of the city of Moscow (https://mosecom.mos.ru/), operates in Moscow. The surface ozone concentration (SOC) is hourly and around-the-clock measured at 17 stations for automatic control of atmospheric pollution (ACAP). The 20 -minute average values are recorded in the database, which allows the measurements to be matched with one-time maximum permissible concentrations. All Mosecomonitoring stations are equipped with high-precision up-to-date instruments, which are included in the State Register of Measuring Instruments and certified by the State Metrological Service (https://mosecom.mos.ru/novosti-i-publikacii/2020/ $06 /$ mosekomonitoring-provodit-masshtabnuyu-zamenu13-stancij-kontrolya-atmosfernogo-vozduxa/). Analytical materials on the state of the environment in Moscow are annually reported (https://www.mos.ru/ eco/documents/doklady/view/). In this review, we present observations from two ACAP stations spaced $\sim 11 \mathrm{~km}$ away: urban (in Maryino) and traffic (on Gagarin Square).

The Kislovodsk High Mountain Scientific Station (KHMSS) was created in the late 1970s by the Obukhov Institute of Atmospheric Physics, Russian Academy of Sciences (IAP RAS, Moscow), on a high-altitude plateau to study the atmosphere and to develop research methods. The nearest populated area is not industrial; the nearest town (20 km away) Kislovodsk is a resort. The vast Shadzhatmaz plateau, located to the north of the Greater Caucasus Mountain Range, is covered with alpine and subalpine meadows. There is a canyon to the south of the plateau, and a nature reserve stretches to mountains of the Side Range of the Caucasus; this territory is depopulated. Elbrus $(5642 \mathrm{~m}$ above sea level) is $46 \mathrm{~km}$ from the KHMSS. A highway 
was recently built $1.5 \mathrm{~km}$ east of the station. Due to the topography, KHMSS is in the free troposphere most of the time. The Greater Caucasus Mountain Range is located almost along the air mass transfer, which is mainly zonal at this altitude; therefore, the lifting effect is significantly weaker as compared to that observed at European high mountain stations.

Continuous measurements of surface ozone with a Dasibi 1008-AH network ozone gas analyzer (Environmental corp., United States) began in 1989. Minute values are automatically recorded around the clock. The air sampling is carried out at an altitude of $4 \mathrm{~m}$ using standard Teflon tubes, which are regularly cleaned. The gas analyzer is calibrated at VNNIM. The ozone measurements were accompanied by measurements of surface concentrations of NOx (with a Model 42C-TE TRACE Level NOx Analyzer), CO (Horiba Ambient CO Monitor APMA-360), and some aerosol characteristics for a long time. Two meteorological stations (DAVIS) currently operate; they require maintenance and calibration. An IR spectrometer of IAP RAS measures the total content of CO and $\mathrm{H}_{2} \mathrm{O}$, and ORIEL complex, the total content of $\mathrm{NO}_{2}$. Total ozone content has been measured with a Brewer N 43 network spectrophotometer since 1989. The KHMSS enters the World Ozonometric Network (no. 282).

The atmospheric air monitoring station Vyatskiye Polyany was created in Vyatskiye Polyany town, in the south of the Kirov region. It is located at a considerable distance from the nearest industrial centers: $97 \mathrm{~km}$ from Naberezhnye Chelny, $131 \mathrm{~km}$ from Kazan, $148 \mathrm{~km}$ from Izhevsk, and $277 \mathrm{~km}$ from Vyatka. There are no industrial enterprises with gas emissions in the town and the region, and the air background is formed due to local motor transport and regional transport. A 3.02 PA chemiluminescent gas analyzer is used to measure surface ozone concentrations. The manufacturer calibrates the analyzer annually using the 1st grade working standard and monthly using a GS-024-2 generator. The measuring complex is mounted in a room on the fourth floor of a residential building in the park area; air is sampled through a Teflon tube at an altitude of $10 \mathrm{~m}$.

The TOR station is an automatic post located on the north-eastern outskirts of the Tomsk Akademgorodok. There are no industrial facilities and highways near the station; there is a small deciduous and coniferous forest around it. The post is affected by the air passing through Tomsk and polluted by industrial and vehicle emissions when air masses are transported eastward. In other cases, air comes from background areas. A 3-02P chemiluminescent gas analyzer is used for ozone measurements. Air is sampled through Teflon tubes at an altitude of $5 \mathrm{~m}$. Measurements at the post are carried out hourly and around the clock. The readings are made at a frequency of $1 \mathrm{~Hz}$, the 10 -minute average values are determined.
The monitoring station of the Fonovaya Observatory is located on the right (eastern) bank of the $\mathrm{Ob}$ river, $60 \mathrm{~km}$ west of Tomsk. The territory between the station and Tomsk is covered mainly by coniferous trees, and immediately near the station, by mixed forest (birch, aspen, and pine). There is a 44-m high mast at the station. Air is sampled through Teflon tubes at altitudes of 10 and $30 \mathrm{~m}$. A TEI model 49C UV ozone analyzer (United States) is used for the measurements, which are carried out hourly and around the clock. The readings are made at a frequency of $4 \mathrm{~Hz}$, and 10 -minute average values are determined. The ozone analyzers at the TOR station and at the Fonovaya Observatory station are calibrated weekly using a GS-024-2 generator.

A surface ozone monitoring post was organized in a suburb of Ulan-Ude, $30 \mathrm{~km}$ east of the city center, in the second quarter of 2020. The post is located in the Udinskaya intermountain depression on the abovefloodplain terrace of the Uda river. There are wetlands to the north. Air samples for determining the surface ozone concentration are taken at an altitude of $2 \mathrm{~m}$ using Teflon tubes; measurements are carried out with a 3.02 PA chemiluminescent gas analyzer. Calibration and zero setting are automatically carried out using built-in microflow sources by gas analyzer processor commands. To control the measurement error, the gas analyzer is periodically calibrated using a Mod. 8500 Monitor Labs calibrator.

\section{MEASUREMENT RESULTS}

\subsection{Surface Air}

We start the analysis with urban stations located in highly populated regions, since high ozone concentrations negatively affect human health. There are six such stations in our survey: two in St. Petersburg, three in Moscow, and one in Obninsk (Fig. 1).

An increase in the ozone concentration from the cold to the warm season is observed at all urban stations, in both the daily average and daily maximum values. Figure 1 also shows periodic fluctuations of both parameters due to synoptic processes and fluctuations in the level of surface air pollution [13-16].

The winter surface ozone content is generally low in Moscow, with insignificant day-to-day fluctuations. Beginning from March, the surface air layer is intensively replenished with tropospheric ozone due to the intensification of tropospheric-stratospheric exchange, and the surface ozone concentration and its daily amplitude increase [16]. These characteristic seasonal differences in the surface ozone concentration were quite pronounced in the first half of 2020 (Figs. 1c-1e).

The average SOC over the first half of 2020 was $40 \mu \mathrm{g} / \mathrm{m}^{3}$ at ACAP Maryino (urban station) and $30 \mu \mathrm{g} / \mathrm{m}^{3}$ at ACAP Gagarin Square (urban, traffic); and 29 and $25 \mu \mathrm{g} / \mathrm{m}^{3}$, respectively, over the period 

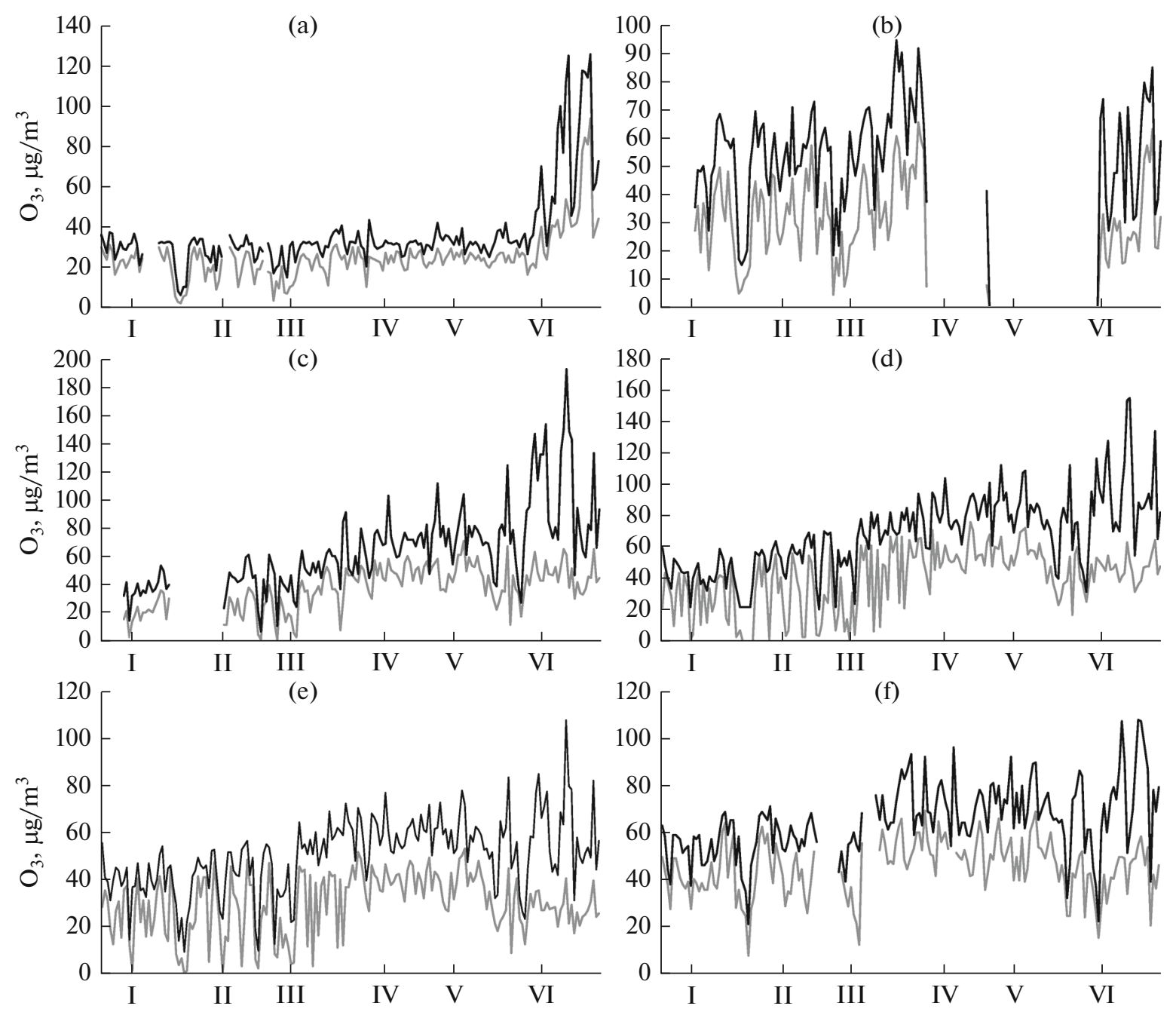

Fig. 1. Daily average (gray curve) and daily maximum (black curve) ozone concentrations in the surface air at (a) OPTEK-P, (b) OPTEK-N, (c) RUDN, (d) ACAP Maryino, (e) ACAP Gagarin Square, and (f) Obninsk stations.

from January to March. Significantly higher differences in SOC at stations of different types were observed in April-June: the daily average SOC for these months was $50 \mu \mathrm{g} / \mathrm{m}^{3}$ at the urban ACAP and $34 \mu \mathrm{g} / \mathrm{m}^{3}$ at the traffic ACAP. The data presented confirm the high spatial inhomogeneity of the surface ozone field, which is characteristic of the megalopolis. Spatial variability of the daily maximum surface ozone concentration $\left(\mathrm{SOC}_{\max }\right)$ is significantly stronger: the averaged $\mathrm{SOC}_{\max }$ at the traffic station was lower by almost $10 \mu \mathrm{g} / \mathrm{m}^{3}$ than at the urban station in the first quarter of 2020 , and by $\sim 25 \mu \mathrm{g} / \mathrm{m}^{-3}$ in the second quarter. Some days, in the second decade of June during heat waves with an increase in daytime temperature to $+28-31^{\circ} \mathrm{C}$, the differences between the daily maxima at the ACAPs under study exceeded $50 \mu \mathrm{g} / \mathrm{m}^{3}$.

A similar dynamics of ozone concentration was recorded in Obninsk (Fig. 1d), though there were some differences. The daily average ozone concentra- tion started decreasing against an increase in the maximal values in late May-June. The relative proximity to Moscow is also reflected in the temporal variations.

Four stations are background: OPTEK-PR, Karadag SBEM, Vyatskiye Polyany, and the Fonovaya observatory. The measurements at these stations are shown in Fig. 2.

One can see in Fig. $2 b$ that $\mathrm{SOC}_{\max }=142 \mu \mathrm{g} / \mathrm{m}^{3}$ for the first half of the year was recorded at the Karadag SBEM at 01:00 on May 16. This nighttime SOC maximum can be explained only by the ozone sink from the upper to the lower atmosphere. During the passage of a front on June 21, the ozone concentration sharply changed: SOC was $96 \mu \mathrm{g} / \mathrm{m}^{3}$ at an air temperature of $28^{\circ} \mathrm{C}$ before precipitation; the temperature dropped by $10^{\circ} \mathrm{C}$ and SOC dropped to $48 \mu \mathrm{g} / \mathrm{m}^{3}$ an hour after the rain. The strongest changes in SOC are associated with frontal precipitation and reflect a "jump" in concentrations during a change in air masses. However, 

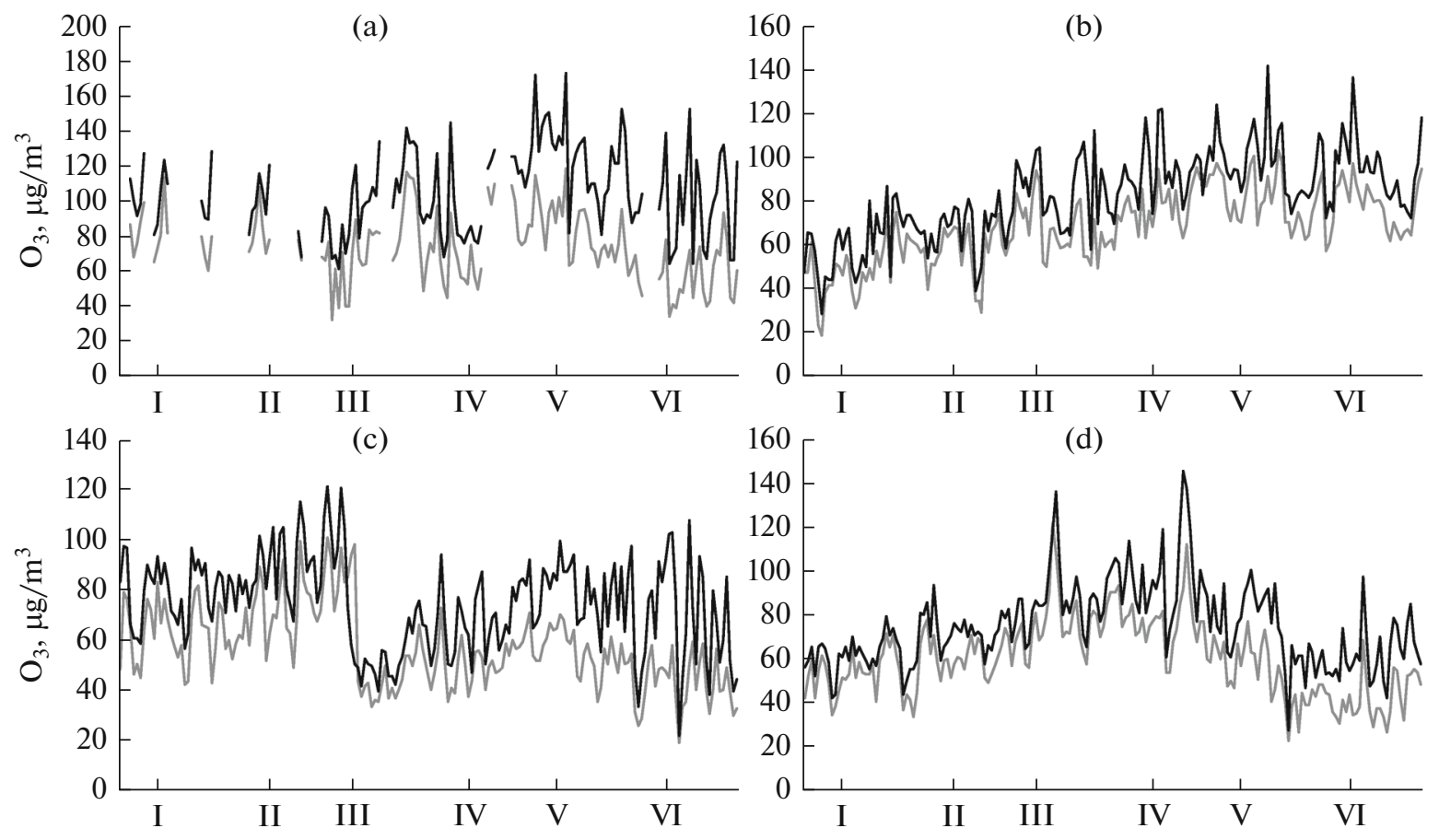

Fig. 2. Daily average (gray curve) and daily maximum (black curve) ozone concentrations in the surface air at (a) OPTEK-PR, (b) Karadag SBEM, (c) Vyatskie Polyany, and (d) Fonovaya Observatory stations.

SOC can both increase and decrease during atmospheric precipitation regardless of type and intensity, as well as of measurement site [17].

In contrast to the plain stations, the behavior of SOC at the Karadag SBEM is characterized by a lower amplitude of the daily variations due to high nighttime ozone concentrations. High nighttime concentrations of surface ozone are due to the features of the surrounding land: the station is located on an open slope at an altitude of $180 \mathrm{~m}$ above sea level. That is why the vertical exchange between the atmospheric boundary layer and the higher layers does not cease at night and, apparently, prevents the formation of thermally stable air stratification [18]. The analysis of synoptic situations in the first and second quarters of 2020 shows that the ozone concentrations were the highest in the case of southern and southeastern air mass transport, which correspond to the direction from the sea relative to the Karadag SBEM position.

Vyatskiye Polyany is the only station on Russian territory where the spring maximum of ozone concentration was clearly pronounced (Fig. 2c), after which the daily average concentration sharply dropped from 90 to $45 \mu \mathrm{g} / \mathrm{m}^{3}$, and the maximal concentration, from 115 to $50 \mu \mathrm{g} / \mathrm{m}^{3}$. Then, the daily average concentration slightly increased with fluctuations due to synoptic processes. The peak values, as can be seen from Fig. 2c, were slightly higher. The authors of [19] explain this behavior of ozone concentration by the fact that the ozone sink to the underlying surface sharply increases after the melting of the snow cover. Hence, if the photochemical generation or deposition of ozone from higher layers remains the same, then its sink sharply increases. This is supported by data [20], which show that the rates of ozone deposition on snow and an open surface can differ by three orders of magnitude.

Two spring peaks can be also distinguished in the ozone concentration at the Fonovaya Observatory in March and April (Fig. 2d). However, the synoptic analysis has shown that they are associated with a violation of the natural seasonal processes, namely, with the arrival of subtropical air on the territory of the region, which, according to [21], is much richer with ozone as compared to usually observed temperate or arctic air masses.

In contrast to urban stations (see Fig. 1), background stations (see Fig. 2) show more active and more variable temporal dynamics of ozone concentration in the first half of 2020. At the same time, both figures show an increase in SOC due to the seasonal increase in the air temperature. The dependence of ozone generation on the air temperature has been ascertained in a number of works [22-24]. This has become especially important in connection with the revealed synchronicity between the ozone concentration maxima and the appearance of heat waves in hot weather [25, 26]. Thus, the above-noted trend towards an increase in TOC values due to a seasonal increase in the air temperature is manifested in other regions of our planet. 
Two stations which monitor ozone in the surface air layer are located in the suburban area: TOR station in Tomsk and the station in Ulan-Ude. According to their location, the dynamics of their surface ozone concentration should be intermediate between urban and background conditions. Their measurement data are shown in Fig. 3.

Since the distance between the TOR station and the Fonovaya Observatory is not large $(60 \mathrm{~km})$, the temporal dynamics of ozone concentration at both stations is similar (Figs. 2c and 3a). The difference is in the higher concentrations, both daily average and maximum, at the suburb station. TOR station, being periodically affected by the plume of Tomsk emissions, with additional amounts of ozone precursors, records higher ozone concentrations.

High ozone concentrations, both daily average and maximum, are typical for the Ulan-Ude station in the period under study (Fig. 3b). Longer cycles of unidirectional changes in the ozone concentration as compared to the above considered stations can be also noted. Unfortunately, the station did not operate for the whole period under study; therefore, it is difficult to estimate the seasonal trend in ozone variations from Fig. $3 b$.

The KHMSS is of special importance (Fig. 4), since it is distinguished by the topography and a temperate climate among all high-altitude stations, due to which it is in the free atmosphere most of the time. The mountainous relief favors the transfer of clean and ozone-enriched air from the stratosphere to the free troposphere. At the same time, polluted air can rise from the valley along the slopes, which are warming up during the day due to the mountain-valley circulation. The intensity of mountain-valley circulation and entry of pollutants depends on the topography. Most highaltitude stations are situated on steep mountain slopes or on their tops and near inhabited valleys, which leads to inflow of pollutants of the planetary-boundary layer along the slopes to the observation site.

The probability of arrival of pollutants from the planetary boundary layer to the KHMSS on the Shadzhatmaz plateau is low. To estimate it, a duplicate measuring complex was mounted in the nearest city of Kislovodsk. It records ozone, aerosols, NOx, and CO. The concentrations and behavior of the impurities at two tropospheric levels were compared during two years with the aim of understanding whether the atmospheric boundary layer in the valley affects the free troposphere on the plateau [27]. Hence, we can state that the long-term series of ozone observations at the KHMSS contains the parameters of the regional or global field of tropospheric ozone [28].

Recording of the regional background, the study of long-range transboundary transport of anthropogenic and natural pollutants from source areas, and identification of sources are important functions of high-altitude stations. These studies have different purposes:

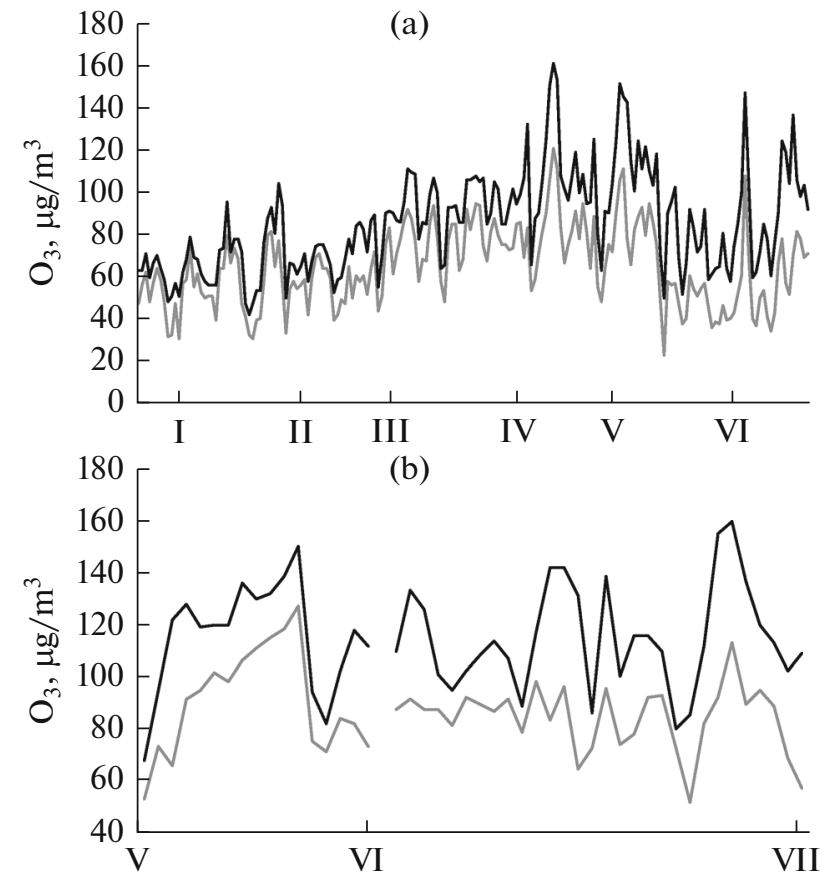

Fig. 3. Daily average (gray curve) and daily maximum (black curve) ozone concentrations in the surface air at (a) TOR and (b) Ulan-Ude stations.

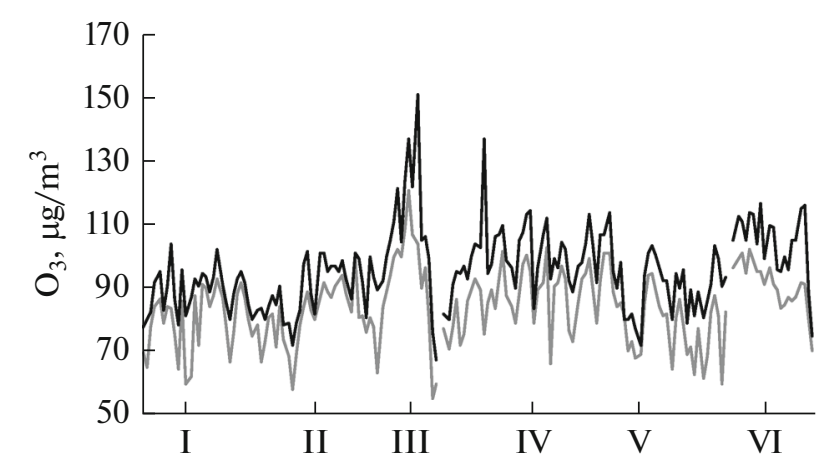

Fig. 4. Daily average (gray curve) and daily maximum (black curve) ozone concentrations in the surface air at KHMSS.

ascertaining conditions under which the region of the Kislovodsk mineral water resort is affected by local wildfires and pollutants from industrial enterprises of Ukraine or from the Caspian oil developments, estimation of the influence of deserts (Kalmykia and Kyzyl-Kum) and Plateau of Iran under changing climate, etc. [29, 30].

The observations in the first quarter of 2020 allow us to note individual events of a significant increase in the surface ozone concentration in March-April with signs of ozone inflow from higher atmospheric layers: an increase in the surface ozone concentration was 


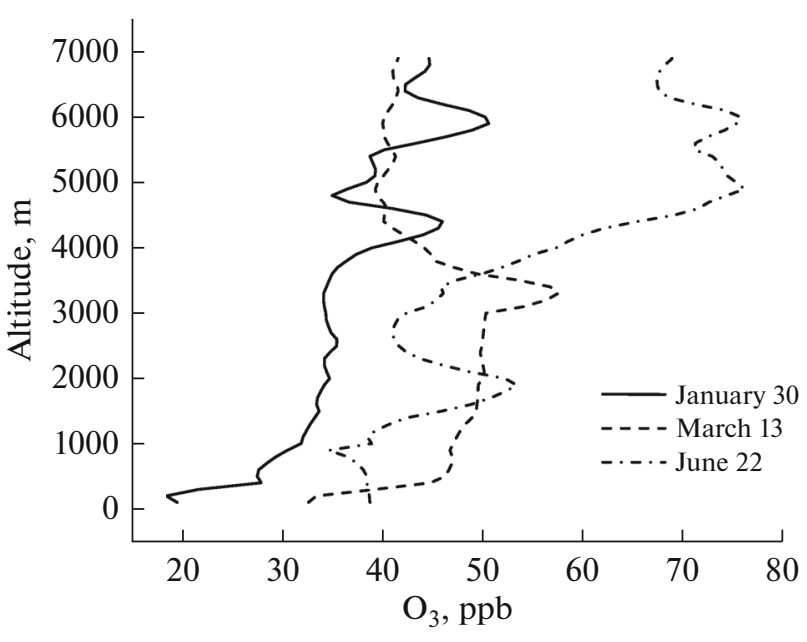

Fig. 5. Vertical ozone distribution over southwestern Siberia in 2020 .

accompanied by a decrease in humidity to $17 \%$ and an increase in the south-east-south-east winds (from the mountains) (Fig. 4). These outflows/intrusions of ozone are possible in discontinuity of the tropopause of the subtropical jet stream migrating over the KHMSS in spring. Other orographic effects are possible, which are accompanied by ozone sinks; they annually occur and form the first local maximum in the seasonal variability in addition to the summer peak. This bimodality reflects two ways of the ozone field formation: vertical transport from the stratosphere and photochemical generation in the troposphere.

Low ozone concentrations (from $20-30 \mu \mathrm{g} / \mathrm{m}^{3}$ ) in the mountains, including at the KHMSS altitude $(2096 \mathrm{~m})$, are recorded under conditions of high relative humidity (over 75\%), which is associated with a local cause, that is, "low" and "ground" clouds. Radiation fogs at the KHMSS are very rare and can last for many days. Heterogeneous ozone deposition is very effective, but no near-zero ozone values are observed. Even very high humidity does not ensure low concentrations of surface ozone in the case of high-intensity convection in a cloud. It should be understood that low surface ozone concentrations of this origin are not a characteristic of the regional field (a cloud is a very local ozone regulator).

\subsection{Boundary Layer and Free Troposphere}

Monthly flights of the Optik airborne laboratory have been carried out by a team from IAO SB RAS since July 1997 with the aim of determining the vertical distribution of atmospheric gases and aerosols. At first, the flights were carried out on an An-30 aircraft [31], then on Tu-134 [32] over the region of Karakansky Bor, $100 \mathrm{~km}$ south-west of Novosibirsk, to exclude the influence of the city. The experiments start at noon, when the photochemical ozone generation is maxi- mal; the flight last 2 hours. The altitude range is from 0 to $7 \mathrm{~km}$. In 2020, not all scheduled flights took place because of COVID-19. The problem of measuring the ozone concentrations under conditions different from background conditions was previously discussed in $[33,34]$. Therefore, three ozonometers simultaneously operate on board: a 3-02P chemiluminescent and two UV (TEI model 49C). The ozonometers are calibrated before a flight with the use of a GS-2 ozone generator.

The measurements of the vertical ozone distribution in Fig. 5 show no ozone generation in the atmospheric boundary layer during the cold period (January-March), when the surface is covered with snow. It was observed only in June. Thus, $\mathrm{O}_{3}$ mainly came from the stratosphere during the cold period. Moreover, the flow was quite weak since the vertical distribution was close to neutral in the middle troposphere.

The data in Fig. 5 significantly differ from the longterm sounding results, which were generalized for the same area in [35]. They showed almost constant photochemical ozone generation in the surface or atmospheric boundary layers. These data also contradict the conclusions [36] about the $20-30 \%$ contribution of sources in European Russia and western Siberia to the photochemical ozone generation. It is difficult to explain this fact. Perhaps, these are features of the natural long-term dynamics of the vertical ozone distribution in the troposphere [35] or the manifestation of the current climate warming [37, 38]. Nevertheless, this vertical ozone distribution in the troposphere makes it possible to explain the nighttime maxima in the surface air layer and the daytime increase due to the development of turbulence [39, 40].

\section{CORRESPONDENCE TO THE RF HYGIENIC STANDARDS}

The maximum permissible concentrations for ozone accepted in the Russian Federation are the strictest in the world. Thus, the information threshold for the population is set to $180 \mu \mathrm{g} / \mathrm{m}^{3}$ in the EU. The World Health Organization has set the moving 8-hour maximum to $120 \mu \mathrm{g} / \mathrm{m}^{3}$. According to the United States national quality standard NAASQS, the maximal hourly average ozone concentration should not exceed $120 \mathrm{ppb}$, and the 8-hour average, $85 \mathrm{ppb}$, which correspond to 240 and $170 \mu \mathrm{g} / \mathrm{m}^{3}$.

In the Russian Federation, the following standards for the surface ozone concentration have been accepted [41, 42]. The daily average maximum permissible concentration $\left(\mathrm{MPC}_{\mathrm{d} . \mathrm{a}}\right)$ is the maximal concentration of a harmful substance in the air of populated areas that should have no direct or indirect inhalation effect on a person (around the clock throughout life); it is equal to $0.03 \mathrm{mg} / \mathrm{m}^{3}$, or $30 \mu \mathrm{g} / \mathrm{m}^{3}$, for ozone. The threshold limit value (TLE) is the maximal concentration of a harmful substance in the air of popu- 
Table 2. Events of ozone concentrations above MPC in the surface air layer on the Russian territory

\begin{tabular}{|c|c|c|c|c|c|}
\hline \multirow{2}{*}{ Station } & \multicolumn{3}{|c|}{$\operatorname{MPC}_{\text {d.a }}\left(30 \mu \mathrm{g} / \mathrm{m}^{3}\right)$} & \multirow{2}{*}{$\begin{array}{c}\text { TLE } \\
\left(100 \mathrm{MPC}_{\mathrm{d} . \mathrm{a}}\right)\end{array}$} & \multirow{2}{*}{$\begin{array}{c}\text { MPC } \\
\left(160 \mathrm{MPC}_{\text {d.a }}\right)\end{array}$} \\
\hline & $1 \mathrm{MPC}_{\mathrm{d} . \mathrm{a}}($ days $/ \%)$ & $2 \mathrm{MPC}_{\mathrm{d} . \mathrm{a}}($ days $/ \%)$ & $3 \mathrm{MPC}_{\text {d.a }}($ days $/ \%)$ & & \\
\hline OPTEC-PR & $134 / 100$ & $106 / 79$ & $25 / 19$ & 13 & 2 \\
\hline OPTEC-P & $23 / 13$ & $2 / 1$ & $0 / 0$ & 0 & 0 \\
\hline OPTEC-N & $50 / 45$ & $2 / 2$ & $0 / 0$ & 0 & 0 \\
\hline Karadag SBEM & $179 / 98$ & $120 / 66$ & $17 / 10$ & 29 & 0 \\
\hline Obninsk & $138 / 86$ & $15 / 9$ & $0 / 0$ & 0 & 0 \\
\hline RUDN & $110 / 72$ & $9 / 6$ & $0 / 0$ & 16 & 1 \\
\hline ACAP Maryino & $132 / 73$ & $26 / 14$ & $0 / 0$ & 12 & 0 \\
\hline ACAP Gagarin Square & $97 / 54$ & $0 / 0$ & $0 / 0$ & 1 & 0 \\
\hline KHMSS & $169 / 100$ & $164 / 97$ & $35 / 21$ & 10 & 0 \\
\hline Vyatskie Polyany & $182 / 100$ & $67 / 37$ & $7 / 4$ & 14 & 0 \\
\hline Fonovaya observatory & $181 / 99$ & $41 / 54$ & $16 / 8$ & 45 & 1 \\
\hline TOR & $178 / 97$ & $48 / 47$ & $8 / 4$ & 13 & 0 \\
\hline Ulan-Ude & $48 / 100$ & $45 / 94$ & $20 / 42$ & 33 & 1 \\
\hline
\end{tabular}

lated areas which does not cause reflex (including subsensory) reactions in the human body (odor, change in the eye illumination sensitivity, etc.) when inhaled for $20 \mathrm{~min}$; TLE for ozone is $0.16 \mathrm{mg} / \mathrm{m}^{3}$, or $160 \mu \mathrm{g} / \mathrm{m}^{3}$. The maximum permissible concentration (MPC) is the maximal concentration of a harmful substance in the air of a working area which, with a duration of work no more than 41 hours per week throughout the entire working life, does not cause diseases or health problems detectable by modern research methods on the job or ulteriorly in the present and next generations. MPC for ozone is equal to $0.1 \mathrm{mg} / \mathrm{m}^{3}$, or $100 \mu \mathrm{g} / \mathrm{m}^{3}$.

Table 2 is compiled on the basis of these standards. It includes the cases of exceeding the above thresholds. Since ozone is not emitted by any industry, but is formed in the atmosphere in photochemical processes, the concept of a working area for this atmospheric component is conventional. There is no boundary of a production site or sanitary zone for ozone since it is everywhere. An agricultural worker in the field or a traffic policeman on duty on a highway is exposed to ozone in the workplace. This is also true for numerous summer residents who cultivate their plots. However, there are cases where the working area for ozone can be defined, for example, an office where copying devices work [43]. Therefore, MPC values above $100 \mu \mathrm{g} / \mathrm{m}^{3}$ are included in Table 2 .

The data in Table 2 shows that, in accordance with the RF standard $\left(\mathrm{MPC}_{\text {d.a }}\right)$, high surface ozone concentrations were measured at all sites under study in the first half of 2020. TOC values twice exceed $M P C_{\text {d.a }}$ almost everywhere, except for urban stations, where ozone is destroyed by vehicle emissions. The ozone concentrations quite often exceed $2 \mathrm{MPC}_{\text {d.a }}$ at background and suburban sites, except for the KHMSS under the influence of the free troposphere. Concentrations of higher than $2 \mathrm{MPC}_{\text {d.a }}$ are observed more than $50 \%$ of days in Karadag, Tomsk region, and Buryatia. The ozone concentrations above $3 \mathrm{MPC}$ and higher than $100 \mu \mathrm{g} / \mathrm{m}^{3}$ are most often recorded at these stations. Single events of ozone concentrations above TLE were recorded at the RUDN station in Moscow (June), in the Tomsk region (April), in UlanUde (June), and in the Leningrad region (May).

\section{CONCLUSIONS}

Thus, the review shows the concentrations of ozone in the surface air layer to exceed the RF hygienic standards at most stations on Russian territory. This requires a more complete analysis of ozoneforming species and the development of measures to reduce their release into the atmosphere.

The mosaic pattern of the data presented is obvious. There are no data for many large Russian regions. This points to a need in increasing the number of ozone monitoring sites.

\section{ACKNOWLEDGMENTS}

The authors are grateful to the Department of Natural Resources Management and Environmental Protection of the city of Moscow and personally to E.G. Semutnikova for the creation of an up-to-date monitoring system comparable to foreign ones, its development, and maintenance at a modern level. The authors are also grateful to the State Atomic Energy Corporation Rosatom for supporting the creation of the RUDN station. 


\section{FUNDING}

We used the data received using the infrastructure of the V.E. Zuev Institute of Atmospheric Optics, Siberian Branch, Russian Academy of Sciences, created and run within State Assignment no. AAAA-A17-117021310142-5, including the Center for Collective Use Atmosphere; the infrastructure of the Institute of Physical Material Science, Siberian Branch, Russian Academy of Sciences, created and run within State Assignment no. AAAA-A 17-117121140006-0; infrastructure of the Vyazemsky Karadag scientific stationNature Reserve of the Russian Academy of Sciences, Branch of [REMOVED HYPERLINK FIELD] Kovalevsky Institute of Biology of the Southern Seas, Russian Academy of Sciences, within State Assignment no. AAAA-A19119012490044-3; the infrastructure of the Obukhov Institute of Atmospheric Physics, Russian Academy of Sciences, within State Assignment no. 0129-2019-0002, and the infrastructure of Prokhorov General Physics Institute, Russian Academy of Sciences, within State Assignment no. AAAAA18-118030690095-8.

\section{CONFLICT OF INTEREST}

The authors declare that they have no conflicts of interest.

\section{REFERENCES}

1. S. P. Perov and A. Kh. Khrgian, Modern Problems of Atmospheric Ozone (Gidrometeoizdat, Leningrad, 1980) [in Russian].

2. V. V. Lunin, M. P. Popovich, and S. N. Tkachenko, Physical Chemistry of Ozone (Moscow State Univ., Moscow, 1998) [in Russian].

3. B. D. Belan, Tropospheric Ozone (Publishing House of IAO SB RAS, Tomsk, 2010) [in Russian].

4. S. V. Razumovskii and G. E. Zaikov, Ozone and Its Reactions with Organic Compounds (Kinetics and Mechnics) (Nauka, Moscow, 1974) [in Russian].

5. WMO Reactive Gases. Bull. No. 2 (WMO, 2018).

6. A. J. Haagen-Smit, "Chemistry and physiology of Los Angeles smog," Ind. Eng. Chem. 44, 1342-1346 (1952).

7. A. J. Haagen-Smit and M. M. Fox, "Ozone formation in photochemical oxidation of organic substances," Ind. Eng. Chem. 48, 1484-1487 (1956).

8. D. R. Blake and F. S. Rowland, "Urban leakage of liquefied petroleum gas and its impact on Mexico city air quality," Science 269 (5226), 953-956 (1995).

9. B. D. Belan, "LPG conversion of vehicles-possible problems," Vestn. Ros. Akad. Nauk 85 (3), 233-239 (2015).

10. N. F. Elanskii, "Russian studies of atmospheric ozone and its precursors in 2015-2018," Izv., Atmos. Ocean. Phys. 56 (2), 141-155 (2020).

11. V. P. Chelibanov, S. N. Kotel'nikov, N. V. Smirnov, and E. A. Yasenko, "Prospects of PAK-8816 hardwaresoftware complex in the construction of a global system for atmospheric air pollution monitoring," Biosfera 7 (1), 26-30 (2015).
12. V. A. Lapchenko and A. M. Zvyagintsev, "Trace atmospheric gases in the Karadag Nature Reserve in Crimea," Atmos. Ocean. Opt. 28 (4), 308-311 (2015).

13. Y. Zhang, H. Mao, A. Ding, D. Zhou, and C. Fu, "Impact of synoptic weather patterns on spatio-temporal variation in surface $\mathrm{O}_{3}$ levels in Hong Kong during 1999-2011," Atmos. Environ. 73, 41-50 (2013).

14. L. Shen, L. J. Mickley, and A. P. K. Tai, "Influence of synoptic patterns on surface ozone variability over the eastern United States from 1980 to 2012," Atmos. Chem. Phys. 15 (19), 10925-10938 (2015).

15. T. Plocostea, R. Calif, and S. Jacoby-Koalyb, "Multiscale time dependent correlation between synchronous measurements of ground-level ozone and meteorological parameters in the Caribbean Basin," Atmos. Environ. 211, 234-246 (2019).

16. A. M. Zvyagintsev, I. N. Kuznetsova, I. Yu. Shalygina, E. A. Lezina, V. A. Lapchenko, M. P. Nikiforova, and V. I. Demin, "Study and monitoring of surface ozone in Russia," Tr. Gidromettsentra Rossiiskoi Federatsii. No. 365, 56-70 (2017).

17. V. G. Arshinova, B. D. Belan, V. A. Lapchenko, E. V. Lapchenko, T. M. Rasskazchikova, D. E. Savkin, T. K. Sklyadneva, G. N. Tolmachev, and A. F. Fofronov, "Changes in surface ozone concentration during precipitation," Atmos. Ocean. Opt. 32 (6), 671-679 (2019).

18. I. Yu. Shalygina, I. N. Kuznetsova, and V. A. Lapchenko, "Surface ozone regime at Kara Dag station in Crimea according to observations in 2009-2018," Gidrometeorologicheskie Issledovaniya Prognozy. No. 2, 102-113 (2019).

19. A. M. Lyudchik, V. I. Pokatashkin, and R. Girgzhdene, "On the relationship between the time of snow cover melting and the appearance of the spring ozone maximum," in Proc. of the Workshop "Problems of Monitoring of Surface (Tropospheric) Ozone and Neutralization of Its Effect" (Institute of General Physics RAS, Moscow, 2013), p. 87-91 [in Russian].

20. O. E. Clifton, A. M. Fiore, J. William, W. J. Massman, C. B. Baublitz, M. Coyle, L. Emberson, S. Fares, D. K. Farmer, P. Gentine, G. Gerosa, A. B. Guenther, D. Helmig, D. L. Lombardozzi, J. W. Munger, E. G. Patton, S. E. Pusede, D. B. Schwede, S. J. Silva, M. Sorgel, A. L. Steiner, and A. P. K. Tai, "Dry deposition of ozone over land: Processes, measurement, and modeling," Rev. Geophys. 58 (1), 1-62 (2020).

21. O. Yu. Antokhina, P. N. Antokhin, V. G. Arshinova, M. Yu. Arshinov, B. D. Belan, S. B. Belan, D. K. Davydov, N. V. Dudorova, G. A. Ivlev, A. V. Kozlov, T. M. Rasskazchikova, D. E. Savkin, D. V. Simonenkov, T. K. Sklyadneva, G. N. Tolmachev, and A. V. Fofonov, "Study of air composition in different air masses," Atmos. Ocean. Opt. 32 (1), 72-79 (2019).

22. H. Ueno and N. Tsunematsu, "Sensitivity of ozone production to increasing temperature and reduction of precursors estimated from observation data," Atmos. Environ. 211, 234-246 (2019).

23. W. C. Porter and C. L. Heald, "The mechanisms and meteorological drivers of the summertime ozone-temperature relationship," Atmos. Chem. Phys. 19 (21), 13367-13381 (2019). 
24. B. D. Belan, D. E. Savkin, and G. N. Tolmachev, "Airtemperature dependence of the ozone generation rate in the surface air layer," Atmos. Oceanic Opt. 31 (2), 187-196 (2018).

25. M. Ma, Y. Gao, Y. Wang, S. Zhang, L. R. Leung, C. Liu, S. Wang, B. Zhao, X. Chang, H. Su, T. Zhang, L. Sheng, X. Yao, and H. Gao, "Substantial ozone enhancement over the North China Plain from increased biogenic emissions due to heat waves and land cover in summer 2017," Atmos. Chem. Phys. 19 (19), 1219512207 (2019).

26. L. Yang, H. Luo, Z. Yuan, J. Zheng, Z. Huang, C. Li, X. Lin, P. K. K. Louie, D. Chen, and Y. Bian, "Quantitative impacts of meteorology and precursor emission changes on the long-term trend of ambient ozone over the Pearl River delta, China, and implications for ozone control strategy," Atmos. Chem. Phys. 19 (20), 1290112916 (2019).

27. N. F. Elanskii and I. A. Senik, "Measurements of the surface ozone concentration at Kislovodsk high mountain station: Seasonal and daily variations," Izv. RAN. Fiz. Atmos. Okeana 31 (2), 251-259 (1995).

28. I. A. Senik, N. F. Elanskii, I. B. Belikov, L. V. Lisitsyna, V. V. Galaktionov, and Z. V. Kortunova, "Main patterns of the temporal variability of surface ozone in the region of the town of Kislovodsk at 870 and $2070 \mathrm{~m}$ above sea level," Izv. Atmos. Ocean. Phys. 41 (1), 6779 (2005).

29. K. A. Shukurov, I. A. Senik, and O. V. Postylyakov, "Effect of long-range transport on the surface ozone at the high mountain scientific station of the Institute of General Physics, Russian Academy of Sciences (Northern Caucasus, Kislovodsk)," in Proc. of the XXVI International Symposium "Atmospheric and Ocean Optics. Atmospheric Physics," July 6-10, 2020, Moscow, Russia (Publishing House of IAO SB RAS, Tomsk, 2020). P. D-211.

30. K. A. Shukurov, O. V. Postylyakov, A. N. Borovski, L. M. Shukurova, A. N. Gruzdev, A. S. Elokhov, V. V. Savinykh, I. I. Mokhov, V. A. Semenov, O. G. Chkhetiani, and I. A. Senik, "Study of transport of atmospheric admixtures and temperature anomalies using trajectory methods at the A.M. Obukhov Institute of Atmospheric Physics," IOP Conf. Ser.: Earth Environ. Sci. 231, 012048 (2019).

https://doi.org/10.1088/1755-1315/231/1/012048

31. V. E. Zuev, B. D. Belan, D. M. Kabanov, V. K. Kovalevskii, O. Yu. Luk'yanov, V. E. Meleshkin, M. K. Mikushev, M. V. Panchenko, I. E. Penner, E. V. Pokrovskii, S. M. Sakerin, S. A. Terpugova, A. G. Tumakov, V. S. Shamanaev, and A. I. Shcherbatov, "The "OPTIK-E" AN-30 aircraft-laboratory for ecological investigations," Atmosp. Ocean. Opt. 5 (10), 658-663 (1992).

32. G. G. Anokhin, P. N. Antokhin, M. Yu. Arshinov, V. E. Barsuk, B. D. Belan, S. B. Belan, D. K. Davydov, G. A. Ivlev, A. V. Kozlov, V. S. Kozlov, M. V. Morozov, M. V. Panchenko, I. E. Penner, D. A. Pestunov, G. P. Sikov, D. V. Simonenkov, D. S. Sinitsyn, G. N. Tolmachev, D. V. Filippov, A. V. Fofonov,
D. G. Chernov, V. S. Shamanaev, and V. P. Shmargunov, "OPTIK Tu-134 aicraft laboratory," Opt. Atmos. Okeana. 24 (9), 805-816 (2011).

33. M. Yu. Arshinov, B. D. Belan, O. A. Krasnov, V. K. Kovalevskii, V. A. Pirogov, A. P. Plotnikov, G. N. Tolmachev, and A. V. Fofonov, "Comparison of ultraviolet and chemiluminescent ozonometers," Atmosp. Ocean. Opt. 15 (8), 656-658 (2002).

34. E. J. Dunlea, S. C. Herndon, D. D. Nelson, R. M. Volkamer, B. K. Lamb, E. J. Allwine, M. Grutter, C. R. Ramos Villegas, C. Marquez, S. Blanco, B. Cardenas, C. E. Kolb, L. T. Molina, and M. J. Molina, "Technical note: Evaluation of standard ultraviolet absorption ozone monitors in a polluted urban environment," Atmos. Chem. Phys. 6 (10), 163-3180 (2006).

35. B. D. Belan, G. N. Tolmachev, and A. V. Fofonov, "Ozone vertical distribution in the troposphere over south regions of Western Siberia," Atmos. Oceanic Opt. 24 (2), 181-187 (2011).

36. K. B. Moiseenko, Yu. A. Shtabkin, E. V. Berezina, and A. I. Skorokhod, "Regional photochemical surfaceozone sources in Europe and Western Siberia," Izv., Atmos. Ocean. Phys. 54 (6), 545-557 (2018).

37. D. Akritidis, A. Pozzer, and P. Zanis, "On the impact of future climate change on tropopause folds and tropospheric ozone," Atmos. Chem. Phys. 19 (22), 1438714401 (2019).

38. P. T. Griffiths, J. Keeble, Y. M. Shin, N. L. Abraham, A. T. Archibald, and J. A. Pyle, "On the changing role of the stratosphere on the tropospheric ozone budget: 1979-2010," Geophys. Rev. Lett. 46 (10) (2020). https://doi.org/10.1029/2019GL086901

39. P. Kalabokas, N. R. Jensen, M. Roveri, J. Hjorth, M. Eremenko, J. Cuesta, G. Dufour, G. Foret, and M. Beekmann, "A study of the influence of tropospheric subsidence on spring and summer surface ozone concentrations at the JRC Ispra station in northern Italy," Atmos. Chem. Phys. 20 (4), 1861-1885 (2020).

40. X. Zhu, Z. Ma, Z. Li, J. Wu, H. Guo, X. Yin, X. Ma, and L. Qiao, "Impacts of meteorological conditions on nocturnal surface ozone enhancement during the summer-time in Beijing, " Atmos. Environ. 225, 117368 (2020)

41. Hygienic standard GN 2.1.6.3492-17 "Maximum permissible concentration (MPC) of pollutants in urban and rural air". Resolution of the Chief State Sanitary Doctor of the Russian Federation No. 165 of December 22, 2017 (as amended on May 31, 2018).

42. Hygienic standard GN 2.2.5.3532-18 "Maximum permissible concentrations (MPC) of harmful substances in the air of the working area". Resolution of the Chief State Sanitary Doctor of the Russian Federation No. 25 of February 13, 2018.

43. A. Ari, "A comprehensive study on gas and particle emissions from laser printers: Chemical composition and health risk assessment," Atmos. Pollut. Res 11. (2), 269-282 (2020). 